\title{
Microbiological Investigation of Braised Meat
}

\author{
N'Guessan Elise $^{1 *}$, Cissé Mohamed ${ }^{1}$, Wognin Séraphin ${ }^{1}$ and Sindic Marianne ${ }^{2}$
}

${ }^{1}$ Department of Biochemistry, Research of Biological Sciences, University Peleforo Gon Coulibaly Korhogo. BP, 1328 Korhogo, Ivory Coast

${ }^{2}$ University of Liege - Gembloux Agro-Bio Tech. Laboratory of Agro-food Quality and Safety, Analysis, Quality and Risk Unit. Passage des Déportés, 2, BE-5030 Gembloux (Belgium)

*Corresponding author

\section{A B S T R A C T}

\section{Keywords}

\section{Bacillus cereus,}

Emetic strains,

Braised meat,

Hygienic

\section{Article Info}

\section{Accepted:}

12 October 2019

Available Online:

10 November 2019
Meat is an important part of human diet with strong implications in health, economy, and culture worldwide. Even if eating meat has recently become subject to criticism for health-related, environmental or humanitarian reasons, it still contribute to the gastronomic pleasure of urban and rural consumers across continents. In West Africa, meat is eaten in several forms, included braised meat which is often sale on street. The possible contamination of this prized foodstuff by the pathogen Bacillus cereus (B. cereus) and in particular by the emetic B. cereus was investigated. For this purpose, a survey to assess the braised meat production conditions was carried out from thirty three (33) vendors in Korhogo city, by using a structured questionnaire, whereas 99braised meat samples were analyzed for the enumeration of total mesophilic bacteria, enterobateria as well as the pathogen B. cereus. B. cereus strains isolated were then screened by polymerase chain reaction (PCR), for emetic strains detection. The results revealed the presence of total bacteria count $(2,51 \pm 0,18$ to $5,04 \pm 0,26 \log$ $\mathrm{cfu} / \mathrm{g})$; Enterobacteriaceae $(8,89 \pm 0,55$ to $9,23 \pm 0,15 \mathrm{log} \mathrm{cfu} / \mathrm{g})$ and B. cereus $(5,66 \pm$ 0,17 to $6,99 \pm 0,08 \mathrm{log} \mathrm{cfu} / \mathrm{g}$ ) in Braised meat. However, none emetic strain was detected among B. cereus isolated. The poor body and work environment hygiene of the braised meat vendors could explain this foodstuff contamination.

\section{Introduction}

Meat is one of the most important sources of animal protein available in the tropics. It is often associated with wealth and a highly nutritional diet (Paredi et al., 2013; Modlinska et al., 2018). Even if eating meat has recently become subject to criticism for health-related, environmental or humanitarian reasons, this foodstuff provides important amount of proteins, vitamins as well as minerals, that keep our body healthy. Besides, meat is one of the primary dietary sources of creatine, which has been suggested to have positive impact on the immune and neurological system (Pereira and Vicente, 2013; Ribas-Agustí et al., 2019). 
Not only does meat production contribute considerably to food security and sustainable land use, but also to the socioeconomic wellbeing of rural communities, and to the gastronomic pleasure of urban and rural consumers across continents (Metzger et al., 2018; Santoze and Gicheha, 2018).

In Ivory Coast, meat is eaten in several forms included the locally called «braised meat » (Roesel, and Grace, 2016). This foodstuff is a barbecue type, cooked outdoors by using live coals or woods. Even if being part of street foods, this dish is very prized by the most of Ivory Coast's population. Therefore, ensuring microbial safety of this foodstuff is an important issue in this context of consumption and production, all the more so as meat constitutes a favorable medium for the proliferation of spoilage and pathogenic microorganisms. Endeed, the high meat protein content provides nutrients for microbial proliferation whereas its neutral $\mathrm{pH}$ and high water activity are favorable conditions for the growth of a wide range of microorganisms. Thus, meat constitutes a potential vehicle for microbial pathogens and was reportedly associated to various bacterial food borne diseases in humans (Fegan and Jenson, 2018; Niyonzima et al., 2018; Kang et al., 2019).

Foods associated with outbreaks of B. cereus diarrhoea frequently include protein-rich foods and researchers have emphasised the importance of the presence of this bacteria or its spores in meat and meat products for the occurrence of such outbreaks (Soares et al., 2012).

In meat production there is a focus on potential faecal pathogens like Salmonella and Escherichia coli, and considerable resources are used to sample the environments for these potential pathogenic bacteria. More other, in central Africa, specially in Rwanda, the microbiological quality of meat consumed within the households, as well as meat-based meals consumed outside the home, was thoroughly investigated (Niyonzima et al., 2016, 2017). However, to the best of our knowledge, no study has yet assessed the occurrence of pathogen such as $B$. cereus in Ivory Coast braised meat. Yet, the incidence of $B$. cereus food poisonings is steadily increasing and lethal cases of $B$. cereus emetic intoxications have been described worldwide (Dierick et al., 2005; Mahler et al., 1997; Naranjo et al., 2011; Shiota et al., 2010; Delbrassinne et al., 2011).

The present study aims to investigate the hygienic conditions of braised meat production as well as the prevalence of $B$. cereus emetic strains in this foodstuff.

\section{Materials and Methods}

\section{Hygiene related to braised meat production}

A survey was conducted to investigate the hygienic conditions related to the production of braised meat, from braised meat vendors of Korhogo, the north of Ivory Coast. For this purpose, thirty three (33) braised meat production places were studied.

The survey was carried out through an interview with the vendors. We remained on the premises while the meat was being prepared, stored and/or sold and we observed the procedure employed by the braised meat handlers.

Informations regarding the braised meat procedures, equipment and hygiene, cleaning and sanitation procedures were collected through a structured questionnaire. The responses from the interview were verified on the site and when necessary corrections were made. 


\section{Braised meat sampling}

A total of ninety-nine thousand (99) braised meat samples were collected from 11 vendors, during four (04) month, at the rate of once a week, from February to May 2019.

Samples were aseptically collected from each seller, placed in sterile stomacher bags (Biorad, Belgium) and held at $4^{\circ} \mathrm{C}$ in a cooling box with freeze packs. Samples were then transported to the laboratory within approximately $1 \mathrm{~h}$, for analysis within the following 24 hours.

\section{Microbiological analysis}

Microbiological analyses were carried out in accordance with the European Regulation EC 2073/2005. Enumeration of bacteria was performed for all samples. Reference methods were used for enumeration of hygiene indicator bacteria namely total bacteria count and Enterobacteriaceae.

The analyses were performed in solid samples, as described ISO 4833-2003 and ISO 215282004 respectively, has a detection limit of 1 $\log \mathrm{cfu} / \mathrm{g}$ (ISO 2007).

Bacillus cereus was qualitatively detected in the braised meat samples by following the ISO7932:2004 standard protocol. The nonselective enrichment step was performed in buffered peptone water (VWR, Belgium), whereas Mannitol Egg Yolk Polymyxin Agar (MYP) (Biorad, Belgium) was used for the isolation of presomptive $B$. cereus colonies. For $B$. cereus confirmation, the characteristic strains isolated were grown overnight on Luria Bertani agar (Biorad, belgium).

Each strain was then diluted in $40 \mathrm{ml}$ of saline water $(0,85 \%)$ before spotting $(3 \mu \mathrm{l})$ on different media: Columbia-based blood agar (containing 5\% sheep blood), erythrocyte agar
(Oxoid) and Mannitol-egg-Yolk-Polymixin (MYP) plates (BioRad). Haemolysis and lecithinase activities were read after $24 \mathrm{~h}$.

\section{Emetic strains detection}

Bacillus cereus strains isolated from braised meat were screened by PCR polymerase chain reaction, for the presence of emetic strains.

For this purpose, Two distinct primer pairs $(\mathrm{Em} 1 \mathrm{~F} / \mathrm{R}$ and $\mathrm{CesF} 1 / \mathrm{R} 2)$ targeting conserved sequence motifs of the cesB NRPS (nonribosomal peptides synthetase) gene were used (Ehling-Schulz et al., 2004; 2005) in this study.

\section{Statistical analysis}

One-way analysis of variance (ANOVA) was used to test the equality of means for normally distributed variables.

\section{Results and Discussion}

Braised meat production and sales conditions in Korhogo city

Table 1 describes the conditions of production and sale of braised meat in the municipality of Korhogo.

Most braised meat sellers $(87.87 \%)$ are illiterate and have poor body and work environment hygiene (84.84\%).

Public slaughterhouses were found to be the main procurement place for meat $(78,78 \%)$.

Furthermore, all the investigated sellers reported to be exposing meat to ambient temperature, before and after cooking process. The average duration of meat exposition remains variable, in function of the meat sales flow. 


\section{Microbiological analyses}

\section{Analytical methods}

The braised meat sold in the municipality of Korhogo were analysed for their bacteria content. Ninety-nine thousand (99) braised meat samples were collected from 11 vendors and investigated. Table 2 describes the levels of hygiene indicator bacteria, namely the total bacteria count and Enterobacteriaceae, as well as the occurrence of B. cereus in braised meat sold indifferent area of Korhogo city. The mean total bacteria count ranged from $8,89 \pm$ 0,55 to $9,23 \pm 0,15 \log \mathrm{cfu} / \mathrm{g}$ and the mean Enterobacteriaceae ranged from. 2,51 $\pm 0,18$ to $5,04 \pm 0,26 \log \mathrm{cfu} / \mathrm{g}$, whereas significant $B$. cereus counts $(5,66 \pm 0,17$ to $6,99 \pm 0,08 \log$ $\mathrm{cfu} / \mathrm{g}$ ) were found in braised meat samples.

Whereas the contamination of braised meat has been carry out though the reaserch of pathogen like Salmonella, Clostridium perfringens (Dibi et al., 2017), there is a lack of information on the contamination of this foodstuff by B. cereus. Yet, the incidence of this pathogen food poisonings is steadily increasing and lethal cases of $B$. cereus emetic intoxications have been described worldwide (Delbrassinne et al., 2011; Schulz et al., 2015; Glasset et al., 2016).

The braised meat sold in different areas of Korhogo city contained significant $B$. cereus, Enterobacteriacae and aerobie mesophilic bacteria counts (Table 2). The contamination of braised meat probably occurred during handling and preparation or post-processing contamination. In 2017, Tewari et al., have isolated enterotoxinogenic B. cereus, harboring enterotoxin genes hblDAC complex, nheABC complex, cytK and entFM, from cooked meat. They suggested that, a relatively higher incidence of these pathogens in meat products, can pose a potential public health threat. The presence of B. cereus in Japan meat products $(18.3 \%)$ and raw meat
(6.6\%) was also reported in a previous study. According to the authors, the main source of $B$. cereus contamination in meat products is contaminated meat product additives (Konuma et al., 1988). Furthermore, B. cereus enterotoxigenic genes were directly detected in Meat and Meat Products, by multiplex Polymerase Chain Reaction in India (Rather $e t$ al., 2011; Sánchez et al., 2014).

In the present study, the braised meat contamination may be explained by the poor body and work environment hygiene of the braised meat vendors. Indeed, the wearing of clean coats and hair covers by braised meat workers were observed in neither sampling area. Masks and gloves were also not worn by the producers. There is also no hand washing between braised meat handling and money handling. Furthermore, The lack of waste containers with covers in the premises of production resulted in braised meat scraps being thrown away by vendors, attracting a variety of insect pests. Recently, different points of braised meat sale located in poorly maintained environments are been highlighted (Dibi et al., 2017). The levels of total mesophilic bacteria and Enterobacteria are in accordance with the lack of hygiene of both meat handling personnel and production premises. Several authors have reportedly associated the microbiological quality of meat to the hygiene of meat handlers and the processing environment (Abdalla et al., 2009; Çalicioğlu et al., 2010; Wheatley et al., 2014). Indeed, the lack of knowledge about good hygienic practices could be linked to the insufficient education of braised meat producers who were mostly illiterate (Table 1).

This low level of schooling witch is probably linked to the poverty could explained the very poor body and work environment hygiene. Another reason of braised meat contamination by $B$. cereus would be the storage conditions. 
Table.1 Braised meat production and sales conditions in Korhogo city

\begin{tabular}{|c|c|c|c|c|c|c|c|c|c|c|c|c|}
\hline Vendors & \multicolumn{3}{|c|}{ Vendors educational level (\%) } & \multicolumn{4}{|c|}{ Meat storage (\%) } & \multicolumn{2}{|c|}{$\begin{array}{c}\text { Workplace and personal } \\
\text { hygiene }(\%)\end{array}$} & \multicolumn{3}{|c|}{ Meat procurement place (\%) } \\
\hline \multirow[t]{3}{*}{33} & Analphabets & $\begin{array}{c}\text { Primary } \\
\text { level }\end{array}$ & $\begin{array}{l}\text { Secondary } \\
\text { level }\end{array}$ & \multicolumn{2}{|c|}{ Before cooking } & \multicolumn{2}{|c|}{ After cooking } & Unhygienic & Hygienic & Farmers & Slaughterhouse & Market \\
\hline & $29(87,88 \%)$ & $\begin{array}{c}4(12,12 \\
\%)\end{array}$ & $0(100,0)$ & $\begin{array}{l}\text { Ambient } \\
\text { temperature }\end{array}$ & $\begin{array}{l}\text { Cold } \\
\text { storage }\end{array}$ & $\begin{array}{l}\text { Ambient } \\
\text { temperature }\end{array}$ & $\begin{array}{l}\text { Cold } \\
\text { storage }\end{array}$ & \multirow[t]{2}{*}{$28(84,84 \%)$} & \multirow[t]{2}{*}{$15,15(\%)$} & \multirow[t]{2}{*}{$\begin{array}{c}2(6,06 \\
\%)\end{array}$} & \multirow[t]{2}{*}{$26(78,79 \%)$} & \multirow[t]{2}{*}{$\begin{array}{c}5(15,15 \\
\%)\end{array}$} \\
\hline & & & & $33(100,0)$ & $0(100,0)$ & $33(100,0)$ & $0(100,0)$ & & & & & \\
\hline
\end{tabular}

Values are numbers (percentage) of braised meat production and sales conditions in Korhogo city. 33 (thirty three)vendors were interviewed on their working conditions.

Table.2 Bacteria counts of braised meat from eleven area in Korhogo city

\begin{tabular}{|c|c|c|c|}
\hline \multirow{2}{*}{} & \multicolumn{3}{|c|}{ Charge moyenne en log cfu/g } \\
\cline { 2 - 4 } & Enterobacteriaceae & $\begin{array}{c}\text { Mesophilic } \\
\text { aerobic } \\
\text { bacteria }\end{array}$ & $\begin{array}{c}\text { Bacillus } \\
\text { cereus }\end{array}$ \\
\hline Natio kobadara & $4,68 \pm 0,08$ & $9,13 \pm 0,11$ & $6,42 \pm 0,36$ \\
\hline Banaforo & $5,22 \pm 0,06$ & $9,11 \pm 0,07$ & $5,66 \pm 0,17$ \\
\hline Cocody & $4,65 \pm 0,07$ & $9,22 \pm 0,03$ & $6,99 \pm 0,08$ \\
\hline Haousabougou & $4,91 \pm 0,21$ & $9,01 \pm 0,16$ & $6,90 \pm 0,26$ \\
\hline Dem & $4,96 \pm 0,06$ & $9,11 \pm 0,04$ & $6,97 \pm 0,07$ \\
\hline Koko & $4,57 \pm 0,34$ & $9,16 \pm 0,18$ & $6,97 \pm 0,22$ \\
\hline Soba & $4,71 \pm 0,26$ & $8,89 \pm 0,55$ & $6,10 \pm 0,68$ \\
\hline Quartier 14 & $4,39 \pm 0,32$ & $9,15 \pm 0,02$ & $6,79 \pm 0,08$ \\
\hline Teguere & $2,51 \pm 0,18$ & $9,11 \pm 0,05$ & $6,07 \pm 0,20$ \\
\hline Petit Paris & $5,04 \pm 0,26$ & $9,23 \pm 0,15$ & $6,91 \pm 0,15$ \\
\hline Air France & $4,82 \pm 0,37$ & $9,00 \pm 0,14$ & $6,26 \pm 0,74$ \\
\hline
\end{tabular}

Values are mean ( \pm standard deviation) of triplicate bacterial loads (in log cfu/g) measurements 
The findings from this study indicate that all vendors stored meat at ambient temperature, before and after cooking process. Even worse, the average duration of meat storage remains variable, in function of the meat sales flow. Since fresh meat is a highly perishable product due to its biological composition, an inadequate storage temperature can favour bacteria development and affect shelf life and freshness. The meat storage conditions can be explained by the low financial capacity of a number of braised meat vendors, which cannot afford the purchase of refrigerator for meat transportation and storage. Our study is in accordance with some authors who reported the transportation of meat under nonrefrigerated temperature conditions in developing countries (Adzitey et al., 2011; Roesel et al., 2014; Nyonzima et al., 2017).

\section{Emetic strain detection}

$B$. cereus strains isolated were investigated by PCR for the presence of emetic strains. Among the $54 \mathrm{~B}$. cereus strains tested, none emetic strain was identified by PCR. Our findings agree with the results from previous study conducted in 2015 by Ehling-Schulz et al., where the scarcity of emetic strains in meat product was reported. According to these authors, it might be speculated that certain food niches provide an advantageous environment for growth/and or antibiotic production, allowing a selective substrate occupancy by emetic strains. Meat dishes rather seems to be the niche of diarrhea bacteria.

There are thus most frequently the vehicles for transmission of the diarrheal form of the illness, caused by $B$. cereus. In addition, after tested a panel of foods regarding the potential of cereulide formation by B. cereus, Agata and collaborators (2002), have observed a very low toxin production in meat despite a good bacterial growth. To our knowledge, this is the first study on prevalence of $B$. cereus emetic strains in the braised meat. while previous studies had mainly focus on potential faecal pathogens like Salmonella and Escherichia coli in meat production. Although heat is mentioned for bacteria destruction or number reduction, significant $B$. cereus was isolated from braised meat. These results suggest that the prevalence of B. cereus is probably higher than previously thought. Although emetic strains were not found in these randomly sampled braised meat, B. cereus may cause severe food poisoning as indicated by previous articles. Therefore, additional studies on a large seize of sample are needed. On account of the poor body and work environment hygiene of the braised meat vendors reported in the present study, it seems essential to sensitize them on good hygienic practices along the braised meat chain and on the risk of disease transmission.

\section{References}

Paredi, G., Sentandreu, M.A., Mozzarelli, A., Fadda, S., Hollung, K., Almeida, A.M., 2013. "Muscle and meat: new horizons and applications for proteomics on a farm to fork perspective". J Prot 88, 58-82.

Modlinska, K., and Pisula, W., 2018 Selected Psychological Aspects of Meat Consumption - A Short Review. Nutrients 10: 1301.

Pereira, P. M., and Vicente, A. F., 2013. Meat nutritional composition and nutritive role in the human diet. Meat Sci 93,586-592.

Ribas-Agustí A., Díaz, A., Sárraga, I., GarcíaRegueiro, C., Castellari, J.A., Castellari, M., 2019. Nutritional properties of organic and conventional beef meat at retail. J. Sci. Food Agric.. 9, 4218-4225Metzger, M.J., MurrayRust, D., Houtkamp, J., Jensen, A., la Riviere, I. et al., (2018). How 
doEuropeans want to live in 2040? Citizen visions and their consequences for European land use. Regional Environmental Change 18,789-802.

HocquetteHocquette, J.F., Ellies-Oury, M.P., Lherm, M., Pineau, C., Deblitz, C., Farmer, L. 2018. Current situation and future prospects for beef production in Europe - A review. Asian-Australas J Anim Sci 31, 1017 - 1035. Santoze, A., Gicheha, M., 2019. The status of cattle genetic resources in West Africa: a review. Advances in Animal and Veterinary Sciences 7, 112-121. Roesel, K., et Grace, D., 2016. Sécurité sanitaire des aliments et marchés informels: les produits d'origine animale en Afrique subsaharienne. Nairobi, Kenya: Institut International de Recherche sur l'Elevage. Tropical Animal Health Production. 50:537-546.

Fegan, N., Jenson, I., 2018. The role of meat in foodborne disease: Is there a coming revolution in risk assessment and management? Meat Sci 144, 22-29. Kang, C.R., Bang, J.H., Cho, S., 2019. Campylobacter jejuni Foodborne Infection Associated with Crosscontamination: Outbreak in Seoul in 2017. J Infect Chemother. 51: 21-27.

Niyonzima, E., Ongol, M.P, Brostaux, Y., Korsak, N., Daube, G., Kimonyo, A., Sindic, M. 2018. Meat retail conditions within the establishments of Kigali city (Rwanda): bacteriological quality and risk factors for Salmonella occurrence. Trop Anim Health Prod. 50, 537-546.

Niyonzima, E., Ongol, M.P., Brostaux, Y., Korsak, N., Daube, G. Kimonyo, A., Sindic, M., 2017. Consumption patterns, bacteriological quality and risk factors for Salmonella contamination in meat-based meals consumed outside the home in Kigali, Rwanda. Food Control 73, 546-554.
Soares, C.M., Kabuki, D.Y., Kuaye, A.Y., 2012. Growth of enterotoxin producing Bacillus cereus in meat substrate at $10^{\circ} \mathrm{C}$ and $30^{\circ} \mathrm{C}$. Braz. J. Microbiol43, 1401-1405.

Niyonzima, E., Ongol, M.P., Brostaux, Y., Koulagenko, N.K., Daube, G., Kimonyo, A., Sindic, M., 2016. Daily intake and bacteriological quality of meat consumed in the households of Kigali, Rwanda. Food Control 69 108114.

Dibi, E.D., Akmel, D.C., Tano, K., Assidjo, N.E., Akaki, D., Montet, D., 2017. Quantitative Assessment of the Risk Linked to the Consumption of Braised Beef Meat "Choukouya" Contaminated with Pathogenic Clostridium perfringens in Côte D'Ivoire. FNS. 8, 1137-1155.

Ehling-Schulz, M., Frenzel, E., Goha, M., 2015. Food-bacteria interplay: pathometabolism of emetic Bacillus cereus. Front Microbiol. 6: 704. Delbrassinne, L.M., Rajkovic, A., Dubois, P., Nguessan, E., Mahillon, J., Van Loco, L., 2011. Determination of Bacillus cereus emetic toxin in food products by means of LC-MS 2 . Food Anal. Methods. 5, 969-979.

Glasset, B., Herbin, S., Guillie, L., Cadel-Six, S., Vignaud, M.L., Grout, J., Pairaud, S., Michel, V., Hennekinne, J.A., Ramarao, N., Brisabois, A., 2016. Bacillus cereus-induced food-borne outbreaks in France, 2007 to 2014: epidemiology and genetic characterisation Euro Surveill 21, 30413

Tewari, A., Abdullah, S., 2015. Bacillus cereus food poisoning: international and Indian perspective. J. Food Sci. Technol52: 2500 -2511.

Sánchez, J.A., Margarita, M., Correa, M., Aceves-Diez, A.E., CastañedaSandoval, L.M., 2014. Direct detection 
of toxigenic Bacillus cereus in dietary complement for children and cassava starch. Rev Colomb Quim 43, 5-9.

Rather, M., Gill, J., Rao, T., Hassan, M., 2011. Direct Detection of Bacillus cereus and its Enterotoxigenic Genes in Meat and Meat Products by Polymerase Chain Reaction. J. Adv. Vet. Res1, 99104.

Abdalla, M.A., Suliman, S.E., Ahmed, O.E., Bakhiet, A.O., 2009. Estimation of bacterial contamination of indigenous bovine carcasses in Khartoum (Sudan). Afr. J. Microbiol. Res. 12, 882-886.

Çalicioğlu, M., Buege, D.R. and Luchansky, J.B., 2010. Effect of pre-evisceration, skin-on carcass decontamination sanitation strategies for reducing bacterial contamination of cattle during skinning. Turk J Vet Anim Sci 34, 261-266.

Wheatley, P., Giotis, E.S., Mckevitt, A.I.,
2014. Effects of slaughtering operations on carcass contamination in an Irish pork production plant.

Irish Vet J 67, 1-6. Adzitey, F., Teye, G.A., Kutah, W.N., Adday, S., 2011. Microbial quality of beef sold on selected markets in the Tamale Metropolis in the Northern Region of Ghana. Livestock Research for Rural Development, 23, 1-9.

Roesel, K., Grace, D., Kago, J., Desissa, F., Spengler, M., Amenu, K. and Heeb, A., 2014. Farmers, traders and retailers are risk managers. In K. Roesel \& D. Grace (Eds.), Food safety and informal markets: Animal products in subSaharan Africa. (1st ed., p. 284). London, United Kingdom: Routledge.

Agata, N., Ohta, M. and Yokoyama, K., 2002. Production of Bacillus cereus emetic toxin (cereulide) in various foods. Int. J. Food Microbiol. 73, 23-27.

\section{How to cite this article:}

N'guessan Elise, Cissé Mohamed, Wognin Séraphin and Sindic Marianne. 2019. Microbiological Investigation of Braised Meat. Int.J.Curr.Microbiol.App.Sci. 8(11): 14551462. doi: https://doi.org/10.20546/ijcmas.2019.811.171 